This is a post-peer-review, pre-copyedit version of an article published in Archaeological and Anthropological Sciences. The final authenticated version is available online at:

https://doi.org/10.1007/s12520-018-0668-9

\title{
Micro-PIXE studies on prehistoric chert tools: elemental mapping to determine Palaeolithic lithic procurement
}

Marta Sánchez de la Torre ${ }^{1,2,3}$, Anikó Angyal ${ }^{4}$, Zsófia Kertész ${ }^{4}$, Stéphan Dubernet ${ }^{1}$, FrançoisXavier Le Bourdonnec ${ }^{1}$, Enikő Papp ${ }^{4}$, Zoltán Szoboszlai ${ }^{4}$, Zsófia Török ${ }^{4}$, Ákos Csepregi ${ }^{4}$, Zita Szikszai ${ }^{4}$

${ }^{1}$ PPVE-Universidad de Zaragoza. Pedro Cerbuna St 12, 50009 Zaragoza, Spain

2 IRAMAT-CRP2A (UMR 5060), CNRS/Université Bordeaux Montaigne. Maison de l'Archéologie, Esplanade des Antilles, 33607 Pessac, France

${ }^{3}$ SERP-Universitat de Barcelona. Montalegre St 6-8, 08001 Barcelona, Spain

${ }^{4}$ Institute for Nuclear Research, Hungarian Academy of Sciences (MTA Atomki), H-4001 Debrecen, P.O. Box 51, Hungary

\begin{abstract}
This paper contributes to an understanding of the distances and choices involved in raw material procurement strategies by Upper Palaeolithic communities through a Pyrenean geoarchaeological case study. Methodologically it involved using Particle Induced X-ray Emission (PIXE) with a focused proton beam to determine the concentration and distribution of elements in geological samples from three natural primary outcrops belonging to two geological formations outcropping in the French side of the Pyrenees. While it was not possible to distinguish the formation through reference to major and minor elements, some variations were revealed at the trace elemental level. With the aim to determine if these elements were associated with the Si matrix or to a specific inclusion, elemental maps were acquired and the elemental composition of the identified inclusions were also determined. These chemical signatures were then compared to those generated from archaeological artefacts from sites in northern Spain as a means of reconstructing the catchment areas used by prehistoric groups for their chert procurement. The results indicate the existence of trans-Pyrenean long distance procurement strategies during the Magdalenian (13700 to the 18800 cal BP).
\end{abstract}


This is a post-peer-review, pre-copyedit version of an article published in Archaeological and Anthropological Sciences. The final authenticated version is available online at:

https://doi.org/10.1007/s12520-018-0668-9

\section{Keywords}

Micro-PIXE, chert, provenance, mapping

\section{Acknowledgements}

Financial support from the Access to Research Infrastructures activity in the Horizon 2020 Programme of the EU (IPERION CH Grant Agreement n. 654028) is gratefully acknowledged for projects ChertPixe (The geochemical characterization of chert by PIXE: a key to understand human mobility in the Pyrenees during the Prehistory) and ChertPixe 2.0 (Characterising the geochemical features of Magdalenian chert tools by PIXE. Tracing prehistoric human mobility in the Pyrenees) (MR: M. Sánchez de la Torre). M. Sánchez de la Torre was also funded by a postdoctoral grant from the Inisitative d'Excellence de l'Université de Bordeaux and a Prestige - Marie-Curie (PRESTIGE-2016-2-0022) and now is funded by a postdoctoral Juan de la Cierva contract from the Spanish Government (FCJI-2016-27911). Authors are indebted to Drs. X. Mangado, J.M. Fullola, O. Mercadal, P. Utrilla and C. Mazo for allowing the analysis of archaeological samples from Parco Cave, Montlleó open-air-site and Forcas I Shelter. Authors are indebted to Dr. Tristan Carter for the English revision of the manuscript.

\section{Introduction}

Chert outcrops exploited as sources of tool-making raw materials are well-documented for the Palaeolithic communities of Europe [1]. Their geological products have primarily been characterised at the macroscopic scale and based on textural and micropalaeontological descriptions. In those cases where a chert outcrop is well delimited geographically and macroscopically there is the possibility of recognising its use archaeologically. Nevertheless, in other cases cherts possess identical macroscopic and petrographic characteristics also when belonging to different geological formations. In these cases geochemical methods must be employed to discriminate between them.

In this paper we characterise the geological products of three chert outcrops in the Central Pyrenees. The Pyrenean mountain range is a mountain chain located in South-Western Europe and naturally dividing in the S-N axis the Iberian Peninsula from the rest of the continental 
This is a post-peer-review, pre-copyedit version of an article published in Archaeological and Anthropological Sciences. The final authenticated version is available online at:

https://doi.org/10.1007/s12520-018-0668-9

Europe. It extends for almost $500 \mathrm{~km}$ from the Bay of Biscay to the Mediterranean Sea and today is the natural border dividing France and Spain. Archaeological works in the Pyrenean region, developed since the last century $[2,3]$ have confirmed that this natural barrier was occupied, at least in the eastern margins, since the Lower Palaeolithic [4, 5]. Studies concerning the homogeneity between Cantabrian and Pyrenean rock art [6], lithic techno-typological analyses [7, 8] and lithic raw material procurement [9] have also demonstrated that contacts between both Pyrenean slopes existed, at least, since the Upper Palaeolithic.

In the northern slopes of the Central Pyrenees a marine chert type presenting parallels with cherts found in several archaeological sites outcrop: these are the Montgaillard flysch cherts and the Buala and Montsaunès cherts. This siliceous raw material appears in a few average but repeatedly in the Magdalenian levels of the three archaeological sites presented here and exposed later on.

The first formation is constituted by the Montgaillard flysch cherts. This silicification originates in the flysch limestones from the Turonian to the Santonian outcropping in primary position near Montgaillard town (Hautes-Pyrénées, France) and in secondary position near Hibarette, Bénac, Saint Martin and Visker (Hautes-Pyrénées, France), where lithic remains of ancient knapping were found [10]. Cherts possess identical features in primary and secondary outcrops. Cortex are regulars, with variable thicknesses and colours from greys to browns with a high variability intrabloc. The micropalaeontological content is composed by sponge spicules and some small benthic foraminifera. In thin sections, a criptoquartz mosaic is the main texture. In few average length-fast chalcedony is identified. Siliceous sponge spicules are also observed. Carbonated elements are constituted by micrite and some skeletal bioclastic elements being in process to be silicide. Metal oxides are abundant and detrital quartz crystals are observed [9].

The Montsaunès-Buala chert are inserted in the Nankin limestones dating from the Middle Maastrichtian and outcropping in the ancient quarry of Montsaunès (Haute-Garonne, France) [11] and the ancient quarry of Buala, near the town of Montgaillard (Hautes-Pyrénées, France) [12]. The micropalaeontological content of these limestones is rich an an association of classical benthic Maastrichtian foraminifera was identified [13]. Cherts possess beige to brown colours with a micropalaeontological content represented by sponge spicules and small foraminifera. In a few samples some Maastrichtian bentic foraminifera were observed. In thin sections, a criptoquartz mosaic is the main texture, and in a few average length-fast chalcedony appears. 
This is a post-peer-review, pre-copyedit version of an article published in Archaeological and Anthropological Sciences. The final authenticated version is available online at:

https://doi.org/10.1007/s12520-018-0668-9

Siliceous sponge spicules are also recognised. Carbonate components are repreented by micrite and bioclastic elements in process to be completely silicified.

Cherts possessing similar characteristics as the three previously described outcrops have been recognised in the archaeological record of the Magdalenian levels from Cova del Parco (Alòs de Balaguer, Spain), Forcas I Shelter (Graus, Spain) and Montlleó open-air site (Prats i Sansor, Spain), with radiocarbon dates from the 13700 to the $18800 \mathrm{cal}$ BP $[14,15]$.

Cova del Parco site (Alòs de Balaguer, Spain) is an archaeological site located in southern Pyrenees, in the Segre river valley at $420 \mathrm{~m}$ asl, in a sheltered area, with a human occupation from the Palaeolithic to the Bronze Age [2, 16-18]. Excavation works started in the 1980s by a team from the University of Barcelona and are still in process. Samples studied come from the Magdalenian levels. The Magdalenian period is well represented in the site, with several levels going from the Middle to the Late Upper Magdalenian [16-18]. The Late Upper Magdalenian period is dated in $14662-15260 \mathrm{cal} \mathrm{BP}^{1}, 14426-15055 \mathrm{cal} \mathrm{BP}$ and $14535-15234 \mathrm{cal} \mathrm{BP}$. The Upper Magdalenian level has three radiometric dates: 15447-16245 cal BP, 15503-16293 cal BP and 15616-16387 cal BP. The Middle Magdalenian is still under excavation and already has two radiocarbon dates: 15778-16592 cal BP and 16022-16839 cal BP.

Forcas I Shelter (Graus, Spain) is located in the eastern province of Huesca, near the Ésera river, tributary of the Cinca river. Discovered by chance in 1990, the site was $90 \%$ destroyed due to gravel exploitation in the area. The site was excavated by a team from the University of Zaragoza. The shelter was occupied repeatedly since the Magdalenian to the Early Mesolithic. Samples studied come from the Magdalenian levels. This period is also well documented in the site, with some occupations from the Lower Magdalenian, dated in 17356-17856 cal BP and the Upper Magdalenian, dated in 14657-15253 cal BP and 14378-15018 cal BP [14, 19].

The open-air site of Montlleó (Prats i Sansor, Spain) is located in the Cerdanya valley, in the high river Segre valley, in a croassroad for human circulation in the Eastern Pyrenees. The site was discovered in 1998 and is still under excavation by a team from the University of Barcelona. Several occupations from the Upper Palaeolithic have been recognised until now. Samples

\footnotetext{
${ }^{1}$ The calendar age for all the radiocarbon dates presented in the paper have been calculated by Online Calpal (quickal2007). CalCurve: CalPal_2007_HULU.68\% range cal BP.
} 
This is a post-peer-review, pre-copyedit version of an article published in Archaeological and Anthropological Sciences. The final authenticated version is available online at:

https://doi.org/10.1007/s12520-018-0668-9

studied here come from the Lower Magdalenian levels, that have been dated in 18247-18822 cal BP, 18585-19058 cal BP and 19852-20416 cal BP [16, 20, 21].

In this paper we first present a compositional analysis of the three geological sources and a selection of artefacts from the three archaeological sites (Fig. 1). As first geochemical analyses were already done and had shown some differences between outcrops regarding some trace elements $[12,22]$, the main goal was to determine where trace elements were placed -within the matrix or in a specific inclusion-, as a means of then being able to detect differences or similarities between specific geological products and artefact raw materials. The most suitable analytical method to achieve the planned goals was Particle Induced X-Ray Emission (PIXE), as it allows obtaining surface analysis and elemental mapping non-destructively.

\section{Study}

\subsection{Sample collection and preparation}

Sixty-nine pieces of chert were selected for the analysis. Forty-nine were geological products from Montsaunès $(n=20)$, Montgaillard $(n=19)$ and Buala $(n=10)$, while 20 were artefacts from the three sites of Cova del Parco (n=9), Montlleó $(n=6)$, and the Forcas I Shelter $(n=5)$. All of them had previously been characterized by their texture and micropalaeontological content and defined as originated in a marine content, possessing identical features as the observed in the geological cherts from the Central Pyrenees.

To avoid the influence of surface alterations/geochemical weathering, geological samples were prepared in squares of $5 \mathrm{~mm} \times 5 \mathrm{~mm}$ having first removed the cortical surface and then polished. However, as it was our aim to also analyse archaeological artefacts in a non-destructive mode, one of the geological samples was analysed without any surface preparation. Results were similar to those obtained for the other geological samples.

\subsection{Analysis}

The analytical quantification of cherts was carried out using the particle induced X-ray emission (PIXE) method with a focused beam, i.e. micro-PIXE. The micro-PIXE measurements were performed at the scanning nuclear microprobe installed on the $0^{\circ}$ beamline of the $5 \mathrm{MV}$ Van de Graaff accelerator of MTA Atomki (Debrecen, Hungary) [23]. 
This is a post-peer-review, pre-copyedit version of an article published in Archaeological and Anthropological Sciences. The final authenticated version is available online at:

https://doi.org/10.1007/s12520-018-0668-9

A proton beam of $3.2 \mathrm{MeV}$ energy focused down to $\sim 4 \mu \mathrm{m} \times 4 \mu \mathrm{m}$ with a current of $50-100 \mathrm{pA}$ was applied to irradiate the samples. With the relatively low beam current the charging up of the samples could be avoided. The scan size was $1 \mathrm{~mm} \times 1 \mathrm{~mm}$. On each sample 2-4 areas of 1 $\mathrm{mm}^{2}$ were measured. At first, elemental maps and summed up X-ray spectra on the full $1 \mathrm{~mm}$ $\times 1 \mathrm{~mm}$ area were recorded. If inhomogeneities were present, e.g. microfossils or mineral inclusions, the scan size and thus the scan area was reduced in order to see these patterns better, and additional measurements were made on the inclusion itself using the selected raster mode. The typical size of these inclusions was in the range of 30-100 $\mu \mathrm{m}$. For each measurement, the accumulated charge was $0.1-0.15 \mu \mathrm{C}$.

For the PIXE measurements, two X-ray detectors placed at $135^{\circ}$ geometry relative to the incident beam were applied to collect the emitted characteristic X-rays. An SDD detector with AP.3 ultra-thin polymer window (SGX Sensortech) with $30 \mathrm{~mm}^{2}$ active surface area was used to measure low and medium energy $\mathrm{X}$-rays $(0.2-12 \mathrm{keV}, \mathrm{Z}>5)$. A permanent magnet protects the detector from the scattered protons. A Gresham type Be windowed $\mathrm{Si}(\mathrm{Li}) \mathrm{X}$-ray detector with $30 \mathrm{~mm}^{2}$ active surface area equipped with an additional kapton filter of $125 \mu \mathrm{m}$ thickness was applied to detect the medium and high energy X-rays $(3-30 \mathrm{keV}, \mathrm{Z}<19)$. The limit of detection (LOD) values decreased from 300 to $30 \mathrm{ppm}$ in the range of $\mathrm{Na}$ to $\mathrm{Ca}$, and for the trace elements the LOD varied from 10 to $50 \mathrm{ppm}$, which are typical for this arrangement[24]. The accumulated charge was monitored with a beam chopper. Detailed description of the measurement setup can be found in [25].

Signals from all detectors (two PIXE and the particle detector of the chopper) were recorded event by event in list mode by the Oxford type OMDAQ2007 data acquisition system [26]. PIXE spectra with better resolution and lower dead time were recorded parallel to this with the SGX DX200 digital DPP.

The obtained PIXE spectra were evaluated with the GUPIXWIN software [27] to determine the elemental composition of the samples. At first, the composition of the matrix was calculated from the spectrum of the SDD detector using the iterative matrix solution method, and then the spectrum of the Be windowed detector was analysed in trace element mode, using the previously obtained matrix and the measured irradiation dose. The X-ray energy range of 3.0$8.5 \mathrm{keV}$ is common for the two PIXE detectors, therefore intensive X-ray lines within this range (e.g. $\mathrm{Ca} \mathrm{K} \alpha$, Ti $\mathrm{K} \alpha, \mathrm{Fe} \mathrm{K} \alpha$ ) were used to normalize the elemental concentrations. 
This is a post-peer-review, pre-copyedit version of an article published in Archaeological and Anthropological Sciences. The final authenticated version is available online at:

https://doi.org/10.1007/s12520-018-0668-9

Analyses of reference materials were carried out in the beginning and at the end of the measurement campaign in order to check the accuracy of the dose measurement and of the precision of the PIXE system. The following standards were used: NIST SRM 610 glass, Corning reference archaeological glasses A and a series of pure metal foils by Advent Research Materials Ltd. with $50 \mu \mathrm{m}$ thickness (Ti, Fe, Ni, Zn, Pb, Sn, Cd, Zr). The calibration of the beam chopper was also done at the beginning and at the end of the campaign. These measurements served also for the determination of the exact measurement conditions (e-ggeometry, solid angles of detectors, absorbent thickness).

Elemental maps were obtained from all the analysed samples, both from the whole area analysed (1000 x $1000 \mu \mathrm{m}$; Full area -full in the raw data-) and the specific area of analysis (100 x $100 \mu \mathrm{m}$; specific area $-\mathrm{Ca}, \mathrm{Ti}, \mathrm{Fe}, \mathrm{K}$ or $\mathrm{Zr}$ in the raw data-) and analysed in detail just to determine the existent relation between elements and the place they occupied in the cherts (matrix or specific inclusion content).

\section{Results and discussion}

\subsection{Statistical analysis for the full area measurements}

For the full area data, principal component analysis (PCA) using the correlation matrix was applied. PCA with the correlation matrix standardizes the data, so elements which are more abundant do not dominate the analysis. Some elements (V, Cu, Ga, Ge, As, Zr, Hf, Pt) were below detection limits in more than $50 \%$ of all cases. These elements were excluded from the statistical analysis. Applying PCA, a good degree of separation between samples from the three geological sources and artefacts from the three archaeological sites was found.

The principal component analysis revealed that $71.95 \%$ of the cumulative variance in the investigated specimens can be explained by four principal components. To distinguish between the sites, Varimax rotation was found to be helpful. Figure 2 shows the plots of the first two components which cover $49.39 \%$ of the total variance. Component 1 (32.13\% of total variance) containing primarily the following elements (factor loading in parentheses): $\mathrm{Al}$ (0.895), $\mathrm{Mg}$ (0.848), $\mathrm{K}(0.830)$ and $\mathrm{Ti}(0.769)$. Component 1 is increasing to the top in the figure. Component 2 (26.07\% of the total variance) which is primarily constructed of $\mathrm{Cr}(0.940), \mathrm{Ni}$ (0.934) and $\mathrm{Fe}(0.659)$ is increasing to the right. The plots show a clear separation of products 
This is a post-peer-review, pre-copyedit version of an article published in Archaeological and Anthropological Sciences. The final authenticated version is available online at:

https://doi.org/10.1007/s12520-018-0668-9

from the Buala source from geological samples from the other two sources (Montgaillard and Montsaunès) and the artefactual raw materials, with higher $\mathrm{Ni}, \mathrm{Cr}$ and $\mathrm{Fe}$ content. Furthermore, the chert artefacts from Forcas and Montlleó are characterized as having higher $\mathrm{Al}, \mathrm{Mg}, \mathrm{K}$ and Ti concentrations which mostly differ from the chemistry of the three geological source products. The chemical profiles of the Montgaillard and the Montsaunès geological sources overlap. Conversely, the chert artefacts from Parco display a similar composition to geological materials from the Montgaillard and Montsaunès sources (Fig. 2).

Figure 3 shows the other two components from the principal component analysis. Component 3 (13.22\% of total variance) is constructed of $\mathrm{S}(0.828), \mathrm{Na}(0.623)$ and $\mathrm{Cl}(0.630)$, increasing to the top, while component 4 (9.34\% of total variance) contains $\mathrm{Ca}(0.832)$ and $\mathrm{Sr}(0.832)$, growing horizontally. Although we can find higher $\mathrm{Ca}$ and $\mathrm{Sr}$ content in the Montgalliard geological samples, they are only slighly different from those of the Montaunès source, PC3 and PC4 cannot be sufficiently used for separation. We can conclude that in the case of the investigated materials, the first two components (PC1 and PC2) can be used to assess the dissimilarities, while PC3 and PC4 are not useful for detecting differences between sources and archaeological materials (Fig. 3).

\subsection{Correlations of the elements in selected areas}

To confirm the results of the PCA performed on the full areas, correlations of the different elements on the selected areas were also assessed, as cherts are characterized not only by their matrices but also by their inclusions. Since the number of cases for some specific elements was low, we present here the distribution independent Spearman rank correlation coefficients. In the case of the artefacts from the Forcas I Shelter, Ti-inclusions containing detectable Nb, with good positive correlations $(\mathrm{r}=0.85, \mathrm{p}<0.05)$ between these elements were found (Fig. 4). Moreover, for the Parco artefacts Ti-inclusions contain a detectable amount of $\mathrm{Zr}, \mathrm{Nb}$ and $\mathrm{Pb}$ while $\mathrm{Zr}, \mathrm{Nb}$ and $\mathrm{Hf}$ in the Montlleó tools. In addition, $\mathrm{Ca}$ - and Ti-inclusions in Parco and Forcas tools show a higher Mg concentration. In the case of Forcas I Shelter Ca- and Tiinclusions, as well as a strong $\mathrm{Mg}-\mathrm{Al}$ correlation $(\mathrm{r}=0.90, \mathrm{p}<0.05)$ was found $(\mathbf{F i g} . \mathbf{5})$.

$\mathrm{Co}$ and $\mathrm{Ni}$ are represented in greater concentrations in the Buala Fe-inclusions. Fe-inclusions with strong Fe-Co correlation were found in Buala $(r=0.78, p<0.05)$ and in Parco $(r=0.90$, $\mathrm{p}<0.05)$ materials (Fig. 6). 
This is a post-peer-review, pre-copyedit version of an article published in Archaeological and Anthropological Sciences. The final authenticated version is available online at:

https://doi.org/10.1007/s12520-018-0668-9

A higher concentration of $\mathrm{Ca}$ mostly appears in the Montgalliard cherts. K-inclusions were identified in the Montlleó, Parco and Montsaunès materials which contain high amounts of $\mathrm{Na}$, while Rb levels are also detectable. Finally, the Montsaunès Zr-inclusions contain detectable traces of $\mathrm{Hf}$ and $\mathrm{W}$, with a strong positive correlation $(\mathrm{r} \geq 0.7, \mathrm{p}<0.05)$ between these elements.

The associations indicated by the correlation coefficients were also checked in the elemental maps acquired during the analysis. The distributions of elements on these maps clearly confirm the correlation results, mostly identifying some trace elements only in specific inclusions (Fig. 7) (Table 1).

Concerning the elemental mapping distribution, some interesting results have been found. While several elements seem to be directly related with the main $\mathrm{Si}$ matrix (e.g. $\mathrm{K}, \mathrm{Al}, \mathrm{Mg}$ ), other appear usually associated to the inclusion content (e.g. Ca, Fe, Ti or $\mathrm{Zr}$ ). Moreover, the analysis of mapping distribution has also demonstrated that other elements are mostly associated with a specific type of inclusion, as is the case of $\mathrm{Sr}$, mostly related with $\mathrm{Ca}$ inclusions, or Hf, mostly appearing within $\mathrm{Zr}$ or Ti inclusions, as the case presented in figure 7. The fact that some elements appear to be related to a specific inclusion content and not to the main silica matrix could be explained by the presence of some mineral inclusions, but more specific studies combining mineralogical and elemental approaches have to been developped to verify these hypotheses.

\section{Conclusions}

The analysis of prehistoric chert artefacts and their comparison with geological chert samples from different Pyrenean outcrops has demonstrated the potential of PIXE analyses for chert sourcing studies, and has provided new data about prehistoric raw materials procurement.

The use of PIXE to determine major, minor and trace elements present in chert artefacts combined with statistical analysis has given some interesting data concerning the existent relation between artefact raw materials and geological samples. Through reference to the PCA graphs a clear relationship has been established between Parco archaeological tools and some of Montlleó artefacts with the geological cherts outcropping in Montsaunès and Montgaillard. However, the chemical signature of the artefacts from Forcas I Shelter, and some of those from 
This is a post-peer-review, pre-copyedit version of an article published in Archaeological and Anthropological Sciences. The final authenticated version is available online at:

https://doi.org/10.1007/s12520-018-0668-9

the Montlleó site, do not match with any of the studied geological outcrops, indicating that other, currently unknown, outcrops were used by these Upper Palaeolithic groups.

Moreover, in addition to the fact that the analysis is done in a non-destructive mode, which is essential when studying cultural material, the possibility to carry out elemental mapping during data acquisition is another advantage of PIXE, as it possible to establish whether the elements appear to be related to the general silica matrix or to a specific inclusion. Next step will be the development of some mineralogical analyses with the aim to determine which minerals are present in the samples and thus, to obtain another parameter to relate archaeological cherts with geological samples.

As some of the analyzed artefacts' elemental profiles do not fit those of the known geological source materials, the next step will be to undertake new fieldwork to locate the missing chert outcrops. 
This is a post-peer-review, pre-copyedit version of an article published in Archaeological and

Anthropological Sciences. The final authenticated version is available online at:

https://doi.org/10.1007/s12520-018-0668-9

\section{References}

[1] C. Duke, J. Steele, Geology and lithic procurement in Upper Palaeolithic Europe: a weightsof-evidence based GIS model of lithic resource potential, Journal of Archaeological Science, 37 (2010) 813-824.

[2] X. Mangado, J.-M. Tejero, J.-M. Fullola, M.-À. Petit, P. García-Argüelles, M. García, N. Soler, M. Vaquero, Nuevos territorios, nuevos grafismos: una visión del Paleolítico superior en Catalunya a inicios del siglo XXI, in: X. Mangado (Ed.) El Paleolítico superior peninsular. Novedades del siglo XXI, SERP. Universitat de Barcelona, Barcelona, 2010, pp. 63-83.

[3] P. Utrilla, L. Montes, C. Mazo, A. Alday, J.M. Rodanés, M.F. Blasco, R. Domingo, M. Bea, El Paleolítico superior en la cuenca del Ebro a principios del siglo XXI. Revisión y novedades, in: X. Mangado (Ed.) El Paleolítico superior peninsular. Novedades del siglo XXI, SERP. Universitat de Barcelona, Barcelona, 2010, pp. 23-61.

[4] C. Falguères, Q. Shao, F. Han, J.J. Bahain, M. Richard, C. Perrenoud, A.M. Moigne, H. Lumley de, New ESR and U-series dating at Caune de l'Arago, France: A key-site for European Middle Pleistocene, Quaternary Geochronolog

y, 30, Part B (2015) 547-553.

[5] H. de Lumley, S. Grégoire, D. Barsky, G. Batalla, S. Bailon, V. Belda, D. Briki, L. Byrne, E. Desclaux, K. El Guenouni, A. Fournier, S. Kacimi, F. Lacombat, M.-A. de Lumley, A.-M. Moigne, J. Moutoussamy, C. Paunescu, C. Perrenoud, V. Pois, J. Quiles, F. Rivals, T. Roger, A. Testu, Habitat et mode de vie des chasseurs paléolithiques de la Caune de l'Arago (600 000400000 ans), L'Anthropologie, 108 (2004) 159-184.

[6] D. Garate, O. Rivero, A. Ruiz-Redondo, J. Rios-Garaizar, Discussion: \&lt;Chronology of western Pyrenean Paleolithic cave art: A critical examination\&gt; by Blanca Ochoa and Marcos García-Díez, Quaternary International, 368 (2015) 88-91.

[7] M. Langlais, Processes of change in Magdalenian societies in the Pyrenean isthmus (20-16 ky cal BP), Antiquity, 85 (2011) 715-728.

[8] M. Langlais, A. Sécher, S. Caux, V. Delvigne, L. Gourc, C. Normand, M. Sánchez de la Torre, Lithic tool kits: A Metronome of the evolution of the Magdalenian in southwest France (19,000-14,000 cal BP), Quaternary International, 414 (2016) 92-107.

[9] M. Sánchez de la Torre, Las sociedades cazadoras-recolectoras del Paleolítico superior final pirenaico: territorios económicos y sociales, SERP. Universitat de Barcelona, Barcelona, 2015. 
This is a post-peer-review, pre-copyedit version of an article published in Archaeological and Anthropological Sciences. The final authenticated version is available online at:

https://doi.org/10.1007/s12520-018-0668-9

[10] J. Barragué, E. Barragué, M. Jarry, P. Foucher, R. Simonnet, Le silex du flysch de Montgaillard et son exploitation sur les ateliers du Paléolithique supérieur à Hibarette (HautesPyrénées), Paleo, 13 (2001) 1-28.

[11] M. Séronie-Vivien, M.R. Séronie-Vivien, P. Foucher, L'économie du silex au Paléolithique supérieur dans le bassin d'Aquitaine, Paleo, 18 (2006) 193-216.

[12] M. Sánchez de la Torre, F.-X. Le Bourdonnec, B. Gratuze, Reconsidering prehistoric chert catchment sources: new data from the Central Pyrenees (Western Europe), Archaeol. Anthropol. Sci., (2017).

[13] M. Bilotte, B. Andreu, Les marnes d'Auzas (Maastrichtien supérieur sous-pyrénéen). Stratigraphie et paléoenvironnements, association d'ostracodes, Revista Española de Micropaleontología, 38 (2006) 309-320.

[14] P. Utrilla, C. Mazo, La Peña de Las Forcas de Graus (Huesca). Un asentamiento reiterado desde el Magdaleniense inferior al neolítico antiguo, Salduie, 7 (2007) 9-37.

[15] X. Mangado, J.-M. Tejero, J.-M. Fullola, M.-À. Petit, P. García-Argüelles, P. García, N. Soler, M. Vaquero, Nuevos territorios, nuevos grafismos: una visión del Paleolítico superior en Catalunya a inicios del siglo XXI, in: X. Mangado (Ed.) El Paleolítico superior peninsular, Monografies del SERP, Barcelona, 2010, pp. 63-83.

[16] J.-M. Fullola, X. Mangado, J.-M. Tejero, M.-À. Petit, M.-M. Bergadà, J. Nadal, P. GarcíaArgüelles, R. Bartrolí, O. Mercadal, The Magdalenian in Catalonia (northeast Iberia), Quaternary International, 272-273 (2012) 55-74.

[17] X. Mangado, J.-M. Fullola, J.-M. Tejero, M.-À. Petit, M. Sánchez de la Torre, R. Bartrolí, Aportacions clau de la Cova del Parco (Alòs de Balaguer, la Noguera, Lleida) al Magdalenià: vint-i-cinc anys de recerca arqueològica, in: Tribuna d'Arqueologia 2012-2013, Generalitat de Catalunya, Barcelona, 2015, pp. 86-99.

[18] X. Mangado, J.-M. Tejero, J.-M. Fullola, M.-À. Petit, M. Sánchez de la Torre, La Cova del parco (Alòs de Balaguer, La Noguera, Lleida). La secuencia magdaleniense, in: E. Carbonell, J.M. Bermúdez de Castro, J.L. Arsuaga (Eds.) Los cazadores recolectores del Pleistoceno y del Holoceno en Iberia y el estrecho de Gibraltar. Estado actual del conocimiento del registro arqueológico, Universidad de Burgos \& Fundación Atapuerca, Burgos, 2014, pp. 152-158. 
This is a post-peer-review, pre-copyedit version of an article published in Archaeological and Anthropological Sciences. The final authenticated version is available online at:

https://doi.org/10.1007/s12520-018-0668-9

[19] P. Utrilla, C. Mazo, La Peña de las Forcas (Graus, Huesca). Un asentamiento estratégico en la confluencia del Ésera y el Isábena, Departamento de Ciencias de la Antigüedad. Universidad de Zaragoza, Zaragoza, 2014.

[20] X. Mangado, M. Sánchez de la Torre, J.M. Fullola, O. Mercadal, N. Rodríguez, J. Grimao, M. Langlais, J.-M. Tejero, J. Nadal, M.-M. Bergadà, Montlleó (Prats i Sansor, La Cerdanya). De la descoberta a la internacionalització, ERA, revista cerdana de recerca, 1 (2015) 25-36.

[21] M.S. de la Torre, X.M. Llach, Where are they coming from? Procurement of siliceous sedimentary rocks in the Magdalenian open-air site of Montlleo (Prats i Sansor, Lleida), Trabajos De Prehistoria, 73 (2016) 7-28.

[22] M. Sánchez de la Torre, F.-X. Le Bourdonnec, S. Dubernet, B. Gratuze, X. Mangado, J.M. Fullola, The geochemical characterization of two long distance chert tracers by ED-XRF and LA-ICP-MS. Implications for Magdalenian human mobility in the Pyrenees (SW Europe), STAR: Science \& Technology of Archaeological Research, 3 (2017) 15-27.

[23] I. Rajta, I. Borbély-Kiss, G. Mórik, L. Bartha, E. Koltay, Á.Z. Kiss, The new ATOMKI scanning proton microprobe, Nuclear Instruments and Methods in Physics Research Section B: Beam Interactions with Materials and Atoms, 109 (1996) 148-153.

[24] I. Uzonvi, I. Raita, L. Bartha, Á.Z. Kiss, A. Nagy, Realization of the simultaneous microPIXE analysis of heavy and light elements at a nuclear microprobe, Nuclear Instruments and Methods in Physics Research Section B: Beam Interactions with Materials and Atoms, 181 (2001) 193-198.

[25] Z. Kertész, Z. Szikszai, Z. Szoboszlai, A. Simon, R. Huszank, I. Uzonyi, Study of individual atmospheric aerosol particles at the Debrecen ion microprobe, Nuclear Instruments and Methods in Physics Research Section B: Beam Interactions with Materials and Atoms, 267 (2009) 2236-2240.

[26] G.W. Grime, M. Dawson, Recent developments in data acquisition and processing on the Oxford scanning proton microprobe, Nuclear Instruments and Methods in Physics Research Section B: Beam Interactions with Materials and Atoms, 104 (1995) 107-113.

[27] J.L. Campbell, N.I. Boyd, N. Grassi, P. Bonnick, J.A. Maxwell, The Guelph PIXE software package IV, Nuclear Instruments and Methods in Physics Research Section B: Beam Interactions with Materials and Atoms, 268 (2010) 3356-3363. 
This is a post-peer-review, pre-copyedit version of an article published in Archaeological and Anthropological Sciences. The final authenticated version is available online at:

https://doi.org/10.1007/s12520-018-0668-9

List of tables:

Table 1 Quantitative results (in ppm) for MO-36 sample. It is specified if the analysis concerns the full area (Full; $1000 \times 1000 \mu \mathrm{m})$ or an inclusion area $(\mathrm{Ti} ; 100 \times 100 \mu \mathrm{m})$. The analytical uncertainty is 2-5 relative\% for major elements and 5-20 relative\% for minor and trace elements

List of figures:

Fig. 1 Location of the chert outcrops and the archaeological sites studied in this paper

Fig. 2 Plot of the first and second principal component

Fig. 3 Plot of the third and fourth principal component

Fig. 4 Ti-Nb correlation in Ti inclusions

Fig. $5 \mathrm{Mg}-\mathrm{Al}$ correlation in $\mathrm{Ti}$ and $\mathrm{Ca}$-inclusions

Fig. 6 Fe-Co correlation in Fe inclusions

Fig. 7 PIXE elemental mapping for MONTLLEÓ-36 sample with a full $1 \mathrm{~mm}^{2}$ area (top) and a Ti selected $\mathrm{mm}^{2}$ area (bottom). In the full area Ti map, the yellow square indicates the zoom selected area. *Selected raster on Ti map 
This is a post-peer-review, pre-copyedit version of an article published in Archaeological and Anthropological Sciences. The final authenticated version is available online at:

https://doi.org/10.1007/s12520-018-0668-9

\section{Table 1}

\begin{tabular}{|c|c|c|c|c|c|c|c|c|c|c|c|c|c|c|c|c|c|c|}
\hline Sample name & $\begin{array}{c}\text { Analysis } \\
\text { Type }\end{array}$ & $\begin{array}{l}\text { Scan } \\
\text { size }\end{array}$ & Site/Outcrop & & $\begin{array}{l}\text { Al } \\
\mathbf{K}\end{array}$ & Si K & K K & $\begin{array}{l}\mathrm{Ca} \\
\mathbf{K}\end{array}$ & Ti K & $\begin{array}{l}\mathrm{Cr} \\
\mathbf{K}\end{array}$ & $\begin{array}{c}\mathbf{F e} \\
\mathbf{K}\end{array}$ & $\mathrm{Sr} \mathrm{K}$ & Y K & $\mathrm{Zr} \mathrm{K}$ & Nb K & Hf $L$ & Ta $\mathbf{L}$ & W L \\
\hline $\begin{array}{l}\text { MONTLLEÓ- } \\
36\end{array}$ & Full & 1000 & Montlleó & $\begin{array}{l}\text { Conc } \\
\text { (ppm) }\end{array}$ & 7500 & 450,000 & 1400 & 3600 & 2400 & 170 & 4100 & 120 & $<$ LOD & $<$ LOD & $<$ LOD & $<$ LOD & $<$ LOD & $<\mathrm{LOD}$ \\
\hline $\begin{array}{l}\text { MONTLLEÓ- } \\
36\end{array}$ & $\mathrm{Ti}$ & 200 & Montlleó & $\begin{array}{l}\text { Conc } \\
\text { (ppm) }\end{array}$ & 9000 & 401,000 & 1900 & 4300 & 49,000 & 100 & 4600 & 100 & $<$ LOD & $<$ LOD & $<$ LOD & $<$ LOD & $<$ LOD & $<\mathrm{LOD}$ \\
\hline $\begin{array}{l}\text { MONTLLEÓ- } \\
36\end{array}$ & $\mathrm{Ti}$ & 200 & Montlleó & $\begin{array}{l}\text { Conc } \\
\text { (ppm) }\end{array}$ & 1900 & 161,000 & 250 & 460 & 315,000 & 180 & 2500 & $<\mathrm{LOD}$ & 100 & 710 & 730 & 70 & 70 & 150 \\
\hline
\end{tabular}


This is a post-peer-review, pre-copyedit version of an article published in Archaeological and Anthropological Sciences. The final authenticated version is available online at:

https://doi.org/10.1007/s12520-018-0668-9

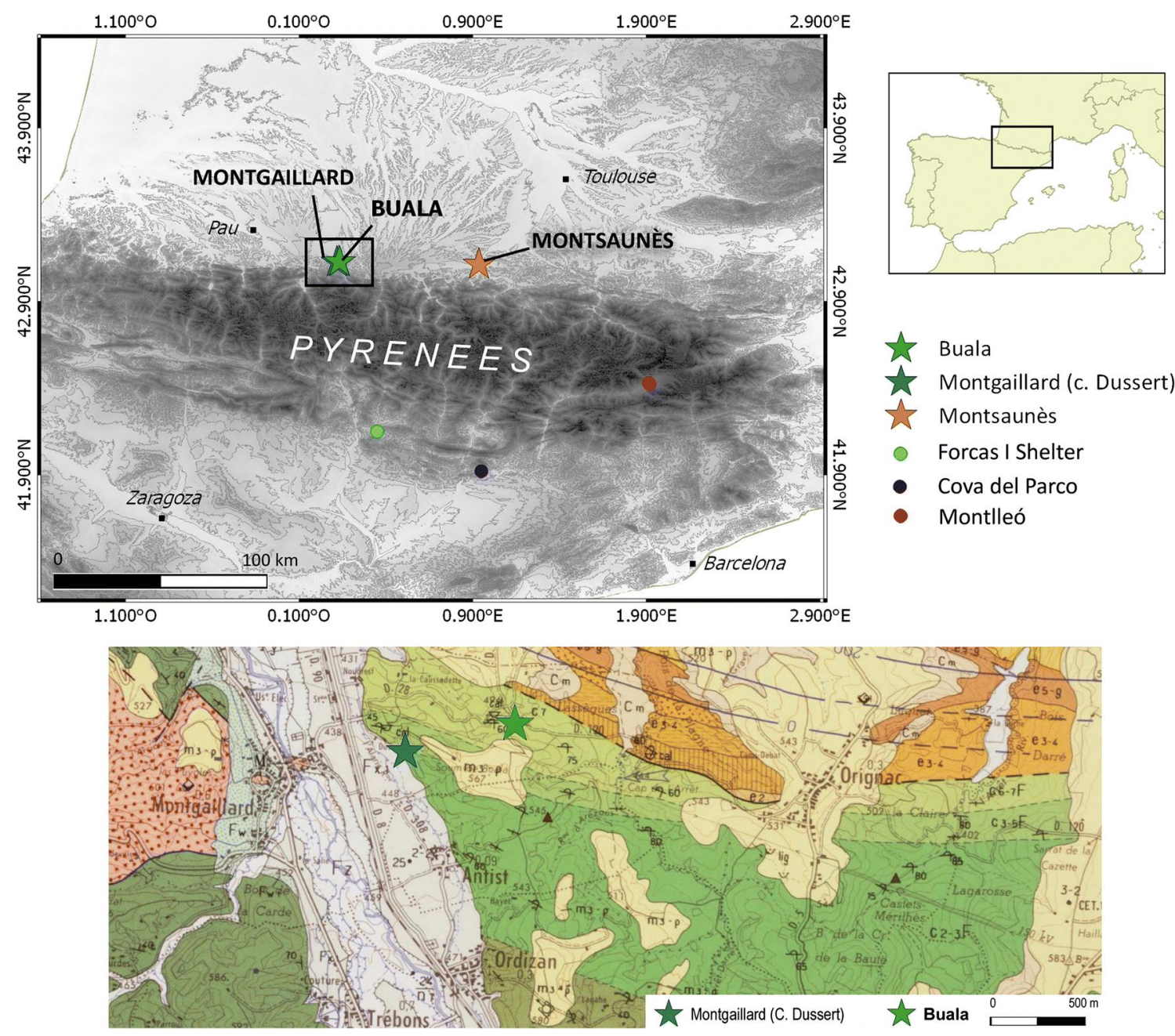


This is a post-peer-review, pre-copyedit version of an article published in Archaeological and Anthropological Sciences. The final authenticated version is available online at:

https://doi.org/10.1007/s12520-018-0668-9
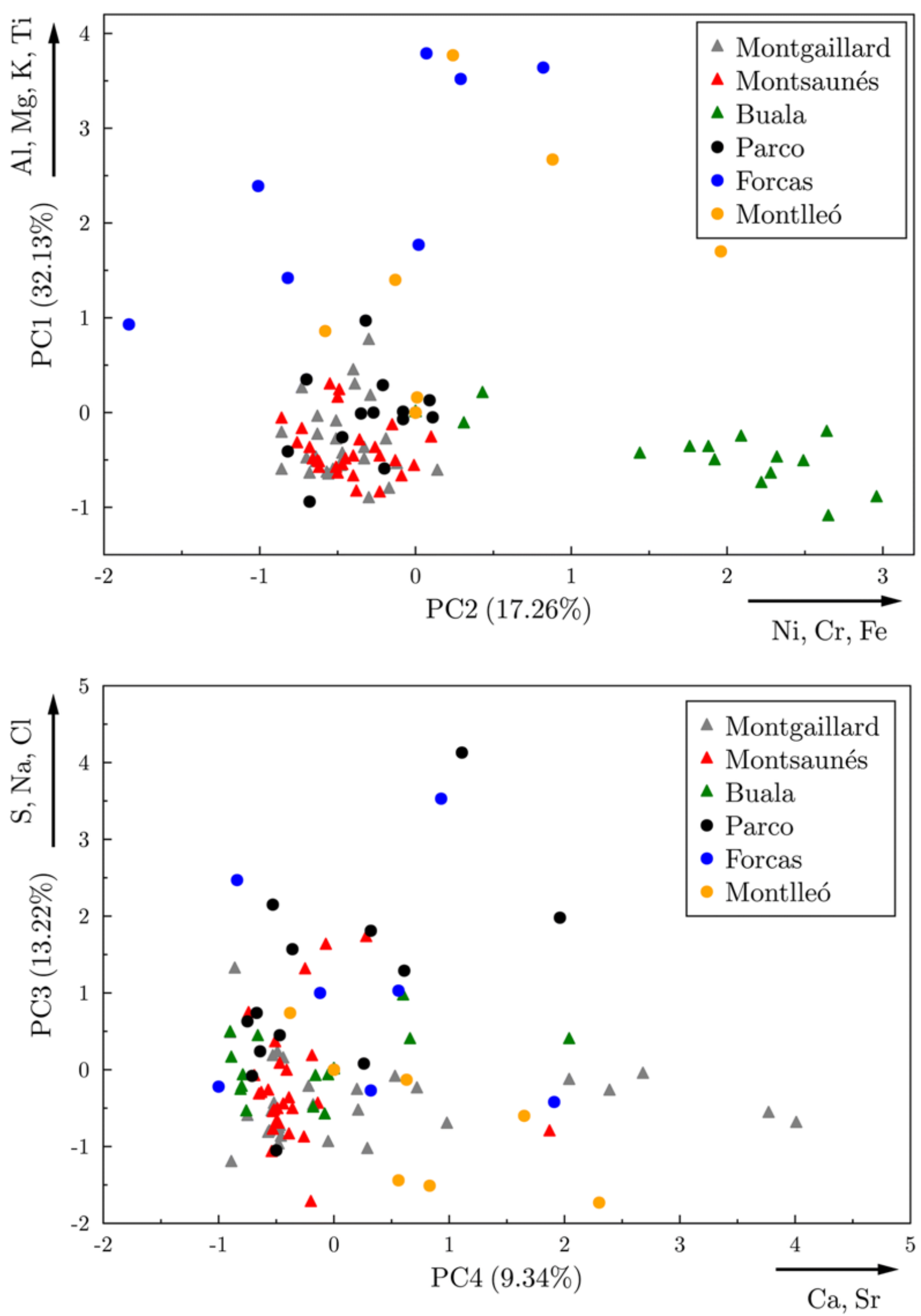
This is a post-peer-review, pre-copyedit version of an article published in Archaeological and Anthropological Sciences. The final authenticated version is available online at:

https://doi.org/10.1007/s12520-018-0668-9
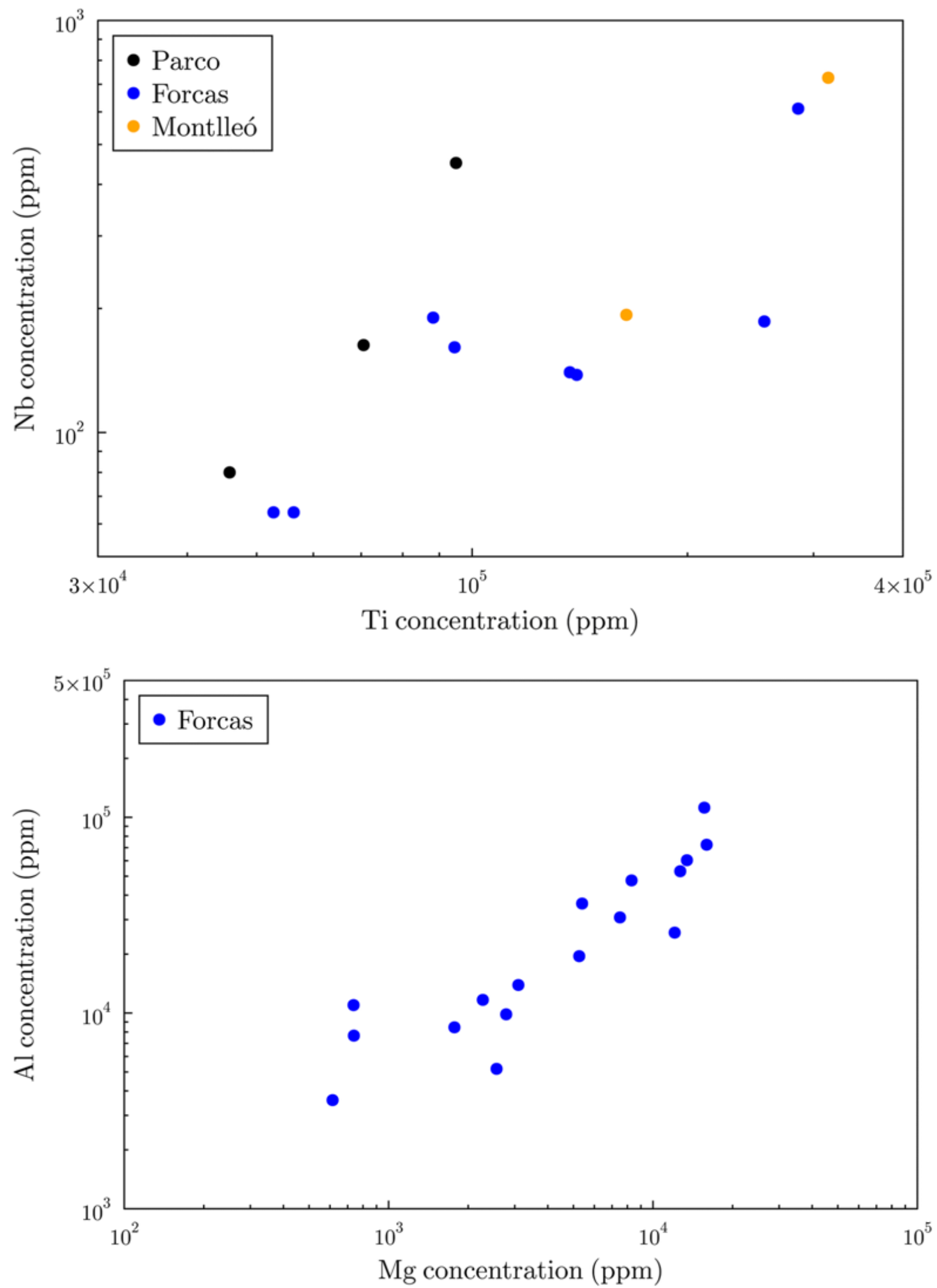
This is a post-peer-review, pre-copyedit version of an article published in Archaeological and Anthropological Sciences. The final authenticated version is available online at:

https://doi.org/10.1007/s12520-018-0668-9

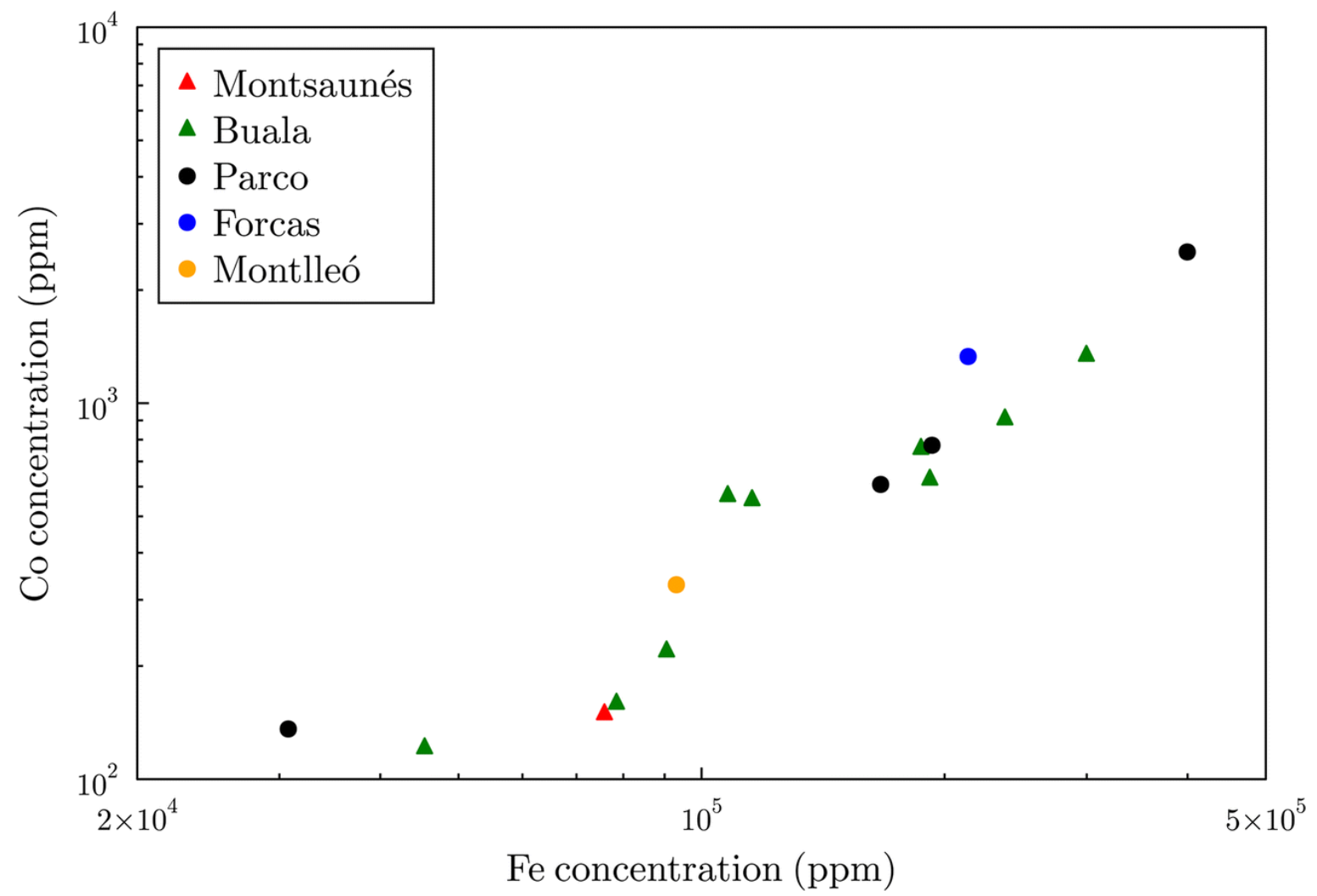


This is a post-peer-review, pre-copyedit version of an article published in Archaeological and Anthropological Sciences. The final authenticated version is available online at:

https://doi.org/10.1007/s12520-018-0668-9
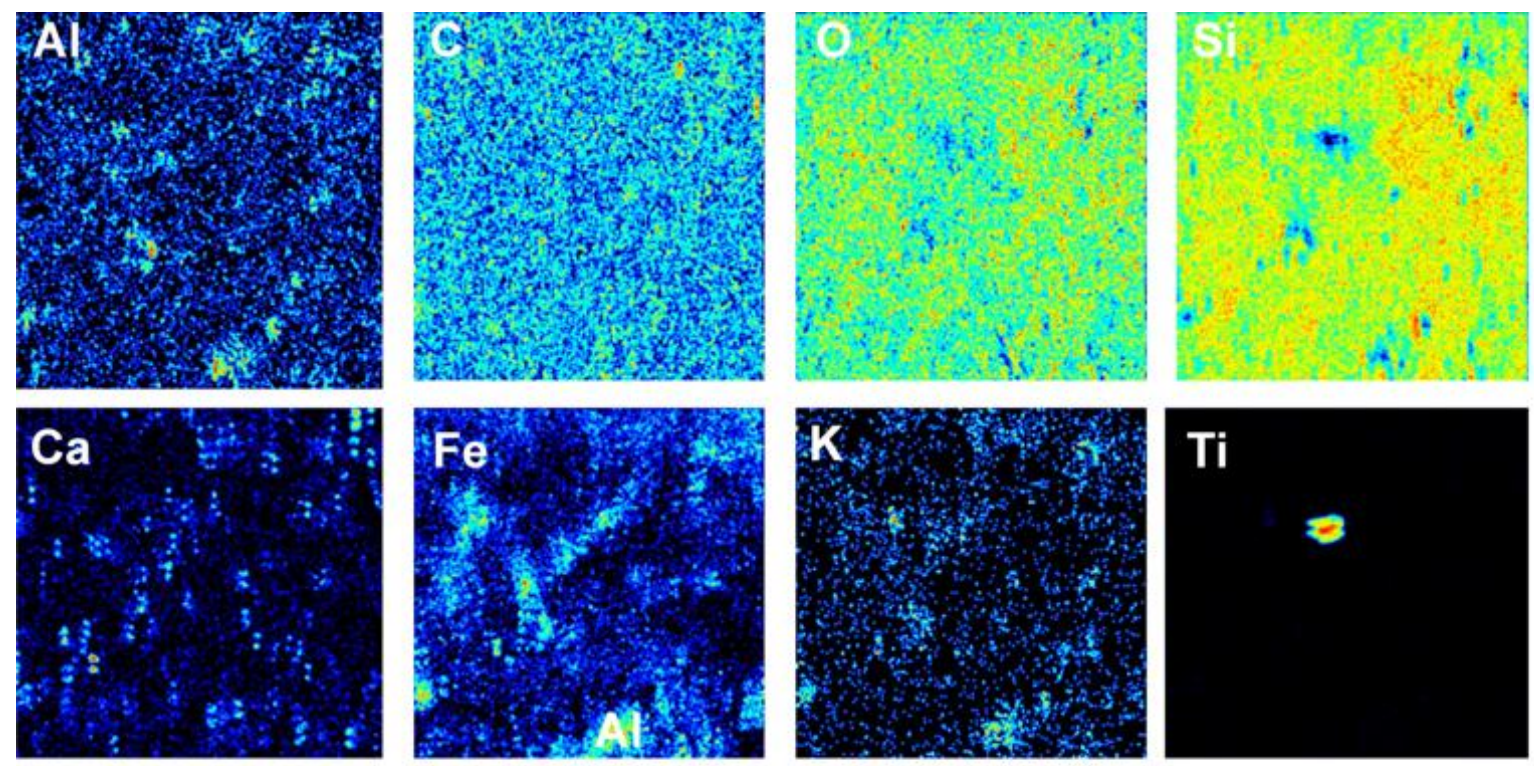

E
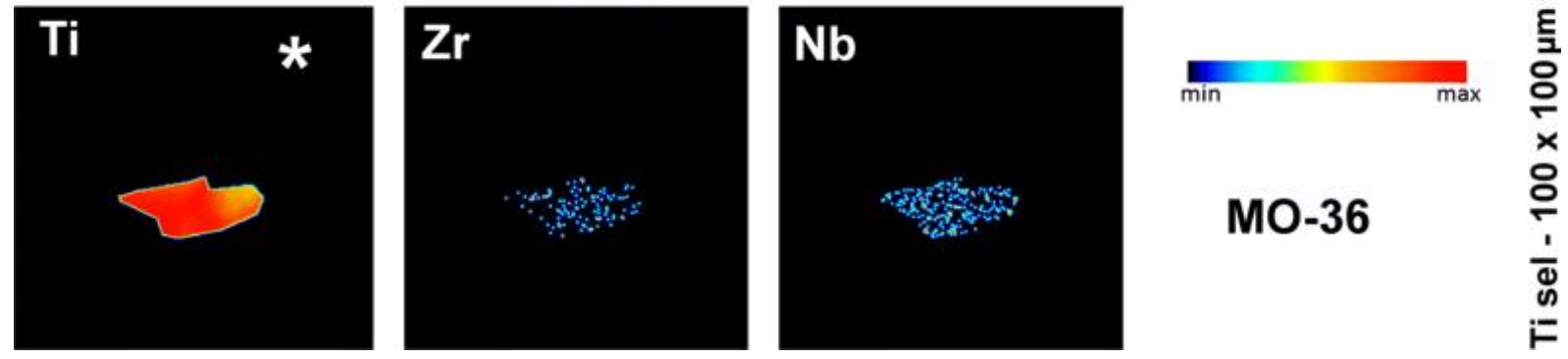